\title{
Создание национальной денежной системы Тувинской Народной Республики (1921-1944 гг.)
}

\author{
Марианна М.-Б. Харунова
}

Тувинский институт комплексного освоения природных ресурсов СО РАН, Российская Федерация,

\section{Рамиль Ш. Харунов}

Улан-Баторский филиал Российского экономического университета им. Г. В. Плеханова, Монголия

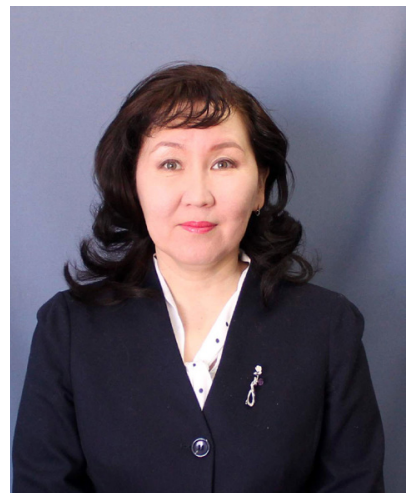

В статье на основе имеющихся научных разработок, материалов музейных коллекций и архивных фондов Республики Тыва рассматривается сложный процесс создания национальной денежной системы Тувы в 1930-1940 г2.

У созданного в 1921 г. государства - Тувинской Народной Республики - развитие финансово-денежной системы было одной из первоочередных задач. Республике пришлось преодолевать сложившееся на рубеже XIX-XX веков валютное многообразие, когда в денежном обороте имели хождение валюты сразу нескольких стран. При помощи СССР была осуществлена денежная реформа, реализованная в несколько этапов: в переходный период с 1921 по 1935 г. в качестве денежных единиц использовались китайские ланы, монгольские тугрики, царские дореволюционные рубли, а затем и советский рубль; в 1935 - 1940 г2. была введена тувинская национальная валюта - акша (1935 и 1940 годов выпуска).

Благодаря проведенным мероприятиям стало возможным дальнейшее экономическое развитие Тувинской Народной Республики, формирование государственного бюджета, налоговой системы и других финансовых институтов, без которых было бы невозмож-

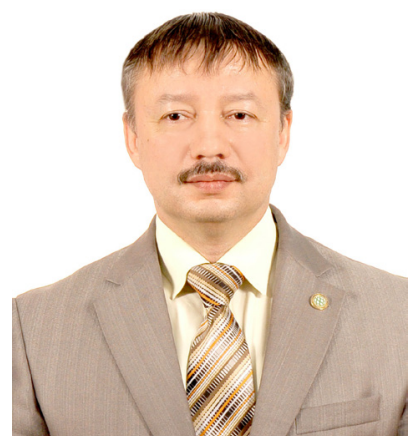
ным становление молодого государства, реализация социально-экономических и культурных преобразований, способствовавщих переходу к современной многоукладной экономике.

Ключевые слова: Тувинская Народная Республика; советский период; история Тувы; натуральный обмен; товарно-денежные отношения; деньги; денежная реформа; советский рубль; акша; тувинская национальная валюта; Тувинский торгово-промышленный банк

Харунова М. М.-Б., Харунов Р. Ш. Создание национальной денежной системы Тувинской Народной Республики (1921-1944 гг.) [Электронный ресурс] // Новые исследования Тувы. 2019, № 3. URL: https://nit.tuva.asia/nit/article/ view/876 (дата обращения: дд.мм.гг.). DOI: 10.25178/nit.2019.3.17

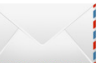

Харунова Марианна Монге-Байыровна - кандидат исторических наук, ведущий научный сотрудник лаборатории математического моделирования Тувинского института комплексного освоения природных ресурсов СО РАН. Адрес: 667007, Россия, г. Кызыл, ул. Интернациональная, д. 117А. Тел.: +7 (394-22) 6-62-18. Эл. адрес: ondar18@ mail.ru ORCID ID:0000-0002-9011-2262

Харунов Рамиль Шатмуратович - кандидат исторических наук, доцент междисциплинарной кафедры Улан-Баторского филиала Российского экономического университета им. Г. В. Плеханова. Адрес: 210351, Монголия, г. Улан-Батор, пр-т Мира, д. 131. Тел.: (+976) 11-450-679. Эл. адрес: ramar33@mail.ru ORCID ID: 0000-0001-7940-5972

Kharunova Marianna Monge-Bairovna, Candidate of History, Leading research fellow, Laboratory of mathematical modeling, Tuvinian Institute for Exploration of Natural Resources, Siberian Branch of the Russian Academy of Sciences. Postal address: 117A, Internatsionalnaya Str., 667010, Kyzyl, Russia. Tel.: +7 (913) 356-10-73. E-mail: ondar18@mail.ru

Kharunov Ramil Shatmuratovich, Candidate of History, Associate Professor, Ulan Bator branch of Plekhanov Russian University of Economics. Postal address: 131 Peace Avenue, Ulan Bator, 210351 Mongolia. Tel.: (+976) 11-450-679. E-mail: ramar33@mail.ru 


\title{
The rise of the national monetary system of the People's Republic of Tuva (1921-1944)
}

\author{
Marianna M.-B. Kharunova \\ Tuvinian Institute for Exploration of Natural Resources, Siberian Branch of the Russian Academy of Sciences, \\ Russian Federation, \\ Ramil Sh. Kharunov \\ Ulan Bataar Branch of Plekhanov Russian University of Economics, Mongolia
}

\begin{abstract}
The article examines a complex process of setting up the national monetary system of Tuva in 1930s-1940s and is based on the existing scholarly research, and the authors' work on museum collections and archival records available in the Republic of Tuva. One of the priority tasks of the People's Republic of Tuva, a state founded in 1921, was to develop a financial system of its own. The republic had to deal with the situation when currencies of several countries were in simultaneous circulation in the region since the turn of twentieth century. The help of the USSR made it possible to carry out a monetary reform, which was implemented in several stages. The transitional period, which lasted from 1921 to 1935, witnessed a simultaneous use of Chinese liangs, Mongolian tögrögs, rubles of both pre-revolution Russian Empire and the Soviet Union as monetary units. Between 1935 and 1940, the republic adopted its own national currency, the aksha (banknotes were issued in 1935 and in 1940).

These measures contributed to the further economic development of the People's Republic of Tuva and helped create its national budget, a fiscal system and other financial institutions, without which the rise of the young state would have been impossible, as well as social, economic and cultural transformations that contributed to a shift to advanced mixed economy.
\end{abstract}

Keywords: People's Republic of Tuva; Soviet period; barter; commodity-money relations; money; monetary reform; Soviet ruble; aksha; Tuvan national currency; the Tuvan Bank of Industry and Trade

For citation:

Kharunova M. M.-B. and Kharunov R. Sh. The rise of the national monetary system of the People's Republic of Tuva (1921-1944). The New Research of Tuva. 2019, № 3. URL: https://nit.tuva.asia/nit/article/view/876 (access date ...). DOI: 10.25178/nit.2019.3.17

\section{Введение}

Геополитические процессы в начале XX века способствовали образованию на территории Центральной Азии нового государства - Тувинской Народной Республики (далее - THР). Трудности становления молодого субъекта международной политики преодолевались параллельно с формированием основ государственности: принятием Конституции, государственных символов (герба, флага), формированием правительства, армии и созданием национальной денежной валюты - акша ${ }^{1}$.

Денежная реформа 1935 г. в ТНР была осуществлена при участии и содействии СССР. Акша стала символом экономических преобразований и системной модернизации, кардинально изменившей традиционный кочевой уклад жизни тувинцев. Тувинские деньги стали ярким образом государственности. Несмотря на то, что валюта просуществовала всего девять лет, она является не только уникальным явлением в мире нумизматики, но и ее название - акша - навсегда закрепилось в современном тувинском языке, обозначая в целом деньги.

Мы уже писали о денежной коллекции периода ТНР, оба акша, хранящихся в фондах Национального музея им. Алдан-Маадыр Республики Тыва (Харунова, Харунов, Санчай, 2019: Электр. ресурс). Как мы отмечали, история становления финансово-денежной системы изучалась в контексте общих процессов социально-экономического развития республики, а также в рамках отдельных публикаций по данному вопросу.

Обобщая степень изученности рассматриваемой темы, можно отметить значительную исследованность исторических предпосылок осуществления денежной реформы в ТНР, в числе которых выделя-

\footnotetext{
${ }^{1}$ Акша - общетюркское слово, означающее деньги, монеты, финансы (Татаринцев, 2015: 84).
} 
ются экономические и политические факторы: введение собственной валюты способствовало развитию товарно-денежных отношений, вытеснивших натуральный обмен, укрепивших базу расчетной системы, налогообложения, формированию госбюджета, что стало серьезным фактором экономического развития молодого государства; собственная денежная система укрепила политический суверенитет республики (Аранчын, 1982; Иезуитов, 1956; Копеел, 1981). Кроме этого, достаточно подробно изучены особенности выпусков тувинских акша (1935 г. и 1940 г.), их объемы и количество, а также вопросы создания государственных органов финансового управления (Ананьин, Рогов, 2014; Бичелдей, 2009).

Изученность особенностей проведения денежной реформы ТНР, позволяет нам выделить этапы в ее реализации: 1) переходный этап 1921-1935 гг., 2) денежная реформа 1935 г., 3) денежная реформа 1940 г.

Цель данной статьи - на основе имеющихся научных исследований и материалов Государственного архива Республики Тыва (далее - ГА РТ) показать эволюцию денежной системы ТНР, которая прошла путь от использования денег других государств до создания национальной валюты - акша, а также сложности ее внедрения в финансово-экономическую сферу и процессы документирования денежного обращения.

\section{Особенности становления государственного бюджета ТНР}

В августе 1921 г. на Всетувинском учредительном хурале было провозглашено образование тувинского государства - Республики Танну- Тува Улус (народа Урянхая) - Тувинской Народной Республики ${ }^{1}$

Правительству ТНР предстояло решить сложнейшую задачу по созданию финансово-кредитной системы и организации торговли, что затруднялось валютным многообразием, унаследованным от предшествовавшей эпохи. Как писал К. А. Бичелдей, «наряду с китайскими юанями, ланами и фынями, монгольскими тугриками, царскими и российскими рублями хождение имели также марки разных стран, японские йены, корейские воны, рубли Азербайджанской и Дальневосточной республик, Закавказской ССР, дензнаки и денежные обязательства Временного Правительства России, Колчаковского правительства Сибири в Омске, Красноярского Общества взаимного кредитования, тибетские дензнаки вплоть до форм «разменных чеков», «краткосрочных денежных обязательств» и иных «печатно-денежных» изданий часто плохого полиграфического исполнения на некачественной бумаге» (Бичелдей, 2009: 18-19). Встречались даже американские доллары и польские злотые (Копеел, 1981: 82). К 1923 г. преимущественное положение в денежном обороте сохранилось за советским рублем, монгольским тугриком и китайскими ланами.

В 1923 г. I Великий Хурал утвердил первый бюджет республики на период с 1 сентября 1923 г. по 1 сентября 1924 г. «В связи с отсутствием тувинской национальной валюты бюджет ТНР до сентября 1925 г. исчислялся в китайских мерах веса, используемых при взвешивании серебра, - ланах и фунах $(1$ лан = 100 фунам = 1 руб. 43 коп. в советских серебряных рублях). С сентября 1925 г. по сентябрь 1927 г. он исчислялся в монгольских тугриках (1 тугрик = 18 г чистого серебра = 1 советский рубль), а с 1927 по 1936 г. - в советских рублях» (История Тувы, 2007: 176).

Ниже в таблице 1 представлены объемы бюджета ТНР (по доходам) по данным министерства финансов ТНР, приведенные в справке ЦК ТНРП от 28 апреля 1944 г. «Финансовая система и финансовое состояние ТНР» (Тульчинский, 1961: 272).

Данные цифры в таблице 1 наглядно демонстрируют не только изменения в валютном исчислении бюджета ТНР с 1923 по 1943 г. (ланы, тугрики, рубли, акша), но и стабильно увеличивавшуюся доходность бюджета, свидетельствовавшую об экономическом росте республики.

Л. И. Тульчинский, основательно изучавший экономику Тувы этого периода, отмечал, что основные доходы в бюджет республики в 1921-1923 гг. поступали за счет таможенной пошлины, арендной платы за пользование приисками, патентов и других сборов. Таможенная пошлина взималась в эти годы из расчета 5 лан пошлины со 100 лан стоимости привезенного в Туву товара. Арендная плата взималась натурой - золотом. На 1 января 1923 г. в государственной казне имелось: золота на сумму 2898 лан 40 фун, серебра - на 430 лан 17 фун, скота - на 175 лан 32 фун и различных товаров на 27038 лан 99 фун (Тульчинский, 1961:271).

${ }^{1}$ В период с 1921 по 1944 гг. в Туве были приняты 7 Конституций, соответственно менялись названия республики: в 1921 г. Республика Танну-Тува Улус (народа Урянхая), в 1923 г. - Народная Республика Танну-Тува, в 1924 г., 1926 гг. - Тувинская Народная Республика, в 1930 г. - Тувинская Аратская Республика, в 1936 г., 1941 г. - Тувинская Народная Республика (Конституции Тувы, 1999: 216). 
Таблица 1. Бюджет ТНР за 1923-1943 г2. (доходы). Table 1. The budget of People's Republic of Tuva in 1923-1943 (income).

\begin{tabular}{|c|c|c|}
\hline \multirow{2}{*}{$N$ o } & Бюджетный период & $\begin{array}{c}\text { Данные министерства финансов ТНР (в } \\
\text { тысячах) }\end{array}$ \\
\hline 1 & до 01.01.1923 & 40,0 лан \\
\hline 2 & с 01.01.1923 по 01.09.1923 & 79,8 лан \\
\hline & Итого: с 01.01.1923 по 01.09.1923 & 119,8 лан \\
\hline 3 & с 01.09.1923 по 01.09.1924 & 282,0 лан \\
\hline 4 & с 01.09.1924 по 01.09.1925 & 312,5 лан \\
\hline 5 & с 01.09.1925 по 01.09.1926 & 418,3 тугр. \\
\hline 6 & с 01.09.1926 по 01.09.1927 & 559,0 тугр. \\
\hline 7 & с 01.09.1927 по 01.09.1928 & 728,4 руб. \\
\hline 8 & с 01.09.1928 по 01.09.1929 & 1438,0 руб. \\
\hline 9 & с 01.09.1929 по 01.09.1930 & 1554,2 руб. \\
\hline 10 & с 01.09.1930 по 01.01.1931 & 604,0 руб. \\
\hline 11 & 1931 & 1818,1 руб. \\
\hline 12 & 1932 & 3314,7 руб. \\
\hline 13 & 1933 & 4067,1 руб. \\
\hline 14 & 1934 & 3990,9 руб. \\
\hline 15 & 1935 & 2818,7 руб. \\
\hline 16 & 1936 & 3709,5 акша \\
\hline 17 & 1937 & 4225,4 акша \\
\hline 18 & 1938 & 5192,0 акша \\
\hline 19 & 1939 & 5417,6 акша \\
\hline 20 & 1940 & 5692,7 акша \\
\hline 21 & 1941 & 7662,0 акша \\
\hline 22 & 1942 & 11497,8 акша \\
\hline 23 & 1943 & 13608,9 акша \\
\hline & & \\
\hline
\end{tabular}

Экономика ТНР в целом была слабой, о чем свидетельствует тот факт, что 45,1\% всех доходов бюджета составляли налоги с населения. В 1925-1926 гг. русское и другое некоренное население, проживавшее в Туве (16-17\% всего населения), уплачивало примерно 24\% всех доходов государственного бюджета THP, 20\% из которых поступали за счет арендной платы (там же: 273). В таблице 2 показана структура налогов.

Таблица 2. Поступления в бюджет от русского и другого некоренного населения ТНР в 1925-1926 г2. Table 2. Budget revenues from Russian and other non-indigenous population of PRT, 1925-1926.

\begin{tabular}{|c|c|c|}
\hline No & Виды налогов & \% от всех доходов / тыс. руб. \\
\hline 1 & арендная плата за пользование золотыми & 11,3 / 46,1 \\
\hline 2 & приисками & $9 / 40,0$ \\
\hline 3 & арендная плата за землю & 2,9 \\
\hline 4 & $\begin{array}{c}\text { сбор от промысловых свидетельств (заготовка выдачу загранпаспортов } \\
\text { соли, рубка лесов), налог на пушнину и рога }\end{array}$ & 0,7 \\
\hline
\end{tabular}

Важной особенностью бюджета ТНР являлась его бездефицитность, что было характерно для «социалистического» бюджета. «Доходы не только покрывали расходы государства, - подчеркивал Тульчинский, - а ежегодно образовывалось превышение доходов над расходами. В 1942 г. такое превышение составило 709,1 и в 1943 г. - 348,4 тыс. акша» (Тульчинский, 1961: 272). Необходимо отметить, что налоговая политика в отношении сельхозпроизводителей была гибкая, с 1927 г. реализовывалась стимулирующая политика для аратских хозяйств. 


\section{Создание органов управления финансово-экономической системы}

Развитие новых отраслей экономики, необходимость денежной реформы требовали государственного управления и создания целого ряда соответствующих органов. При министерстве финансов, начавшем свою деятельность в 1922 г., был создан отдел торговли. В сентябре 1922 г. начал функционировать потребсоюз Русской самоуправляющейся трудовой колонии ${ }^{1}$, в 1923 г. создана Танну-Тувинская (Урянхайская) контора Сибгосторга, в 1924 г. - Тувинский центральный кооператив (Тувинценкооп, ТЦК). Основная масса товарооборота Тувинценкоопа состояла из товаров, получаемых из СССР (Иезуитов, 1956: 115).

По соглашению с Госбанком СССР 25 июля 1925 г. учрежден Тувинский торгово-промышленный банк (Тувинбанк) с основным капиталом в 300000 золотых рублей, 200000 из которых составлял взнос Госбанка СССР (Копеел, 1981: 83). «Банк сыграл решающую роль в укреплении экономического положения республики, содействовал развитию всех отраслей народного хозяйства, способствовал укреплению денежного обращения в стране» (История Тувы, 2007: 176).

Государственный и другие банки СССР предоставляли Тувинбанку долгосрочные кредиты на значительные суммы для покупки машин, оборудования, на дорожное и коммунальное строительство. Подавляющая сумма денежных средств, выданных на развитие сельского хозяйства ТНР, являлись безвозвратными кредитами (Иезуитов, 1956: 120). До конца 1920-х гг. Тувинбанк занимался хозяйственной и коммерческой деятельностью: торговлей, строительством, разведкой недр. Заготовку хлеба, размол зерна, реализацию муки Тувинбанк курировал до 1932 г. Первые предприятия горнорудной промышленности и сельскохозяйственные государственные предприятия были организованы Тувинбанком (Аранчын, 1982:146). Значительную часть отчислений прибыли Тувинбанка Госбанк СССР как равноправный акционер оставлял республике на хозяйственно-культурное развитие (Копеел, 1981: 83).

Необходимо отметить, что Советский Союз к 1924 г. завершил собственную денежную реформу. В октябре 1921 г. был учрежден Государственный банк РСФСР, создание которого обошлось казне в 2 трлн. руб. совзнаками, что составило с учетом эмиссии за октябрь 1921 г. 31\% всей находящейся в обращении денежной массы. «Законом от 11 ноября 1922 г. Государственному банку было предоставлено право выпуска банковских билетов достоинством в 1, 2, 3, 5, 10, 25 и 50 червонцев. Золотое содержание червонца было определено в 7,74234 г чистого золота, т.е. равнялось содержанию золота старой дореволюционной золотой монеты» (История Банка России ..., 2010: 114). К 1924 г. была проведена унификация денежного обращения. Денежные знаки, выпускавшиеся в Закавказье, Средней Азии, Дальнем Востоке, заменялись на общесоюзные деньги. В обращении находились только устойчивые червонцы, казначейские билеты и разменная монета (Денежное обращение ..., 1965: 63). Реформа обеспечила единство денежной системы на всей территории СССР.

\section{Переходный этап денежной реформы (1921-1935 г2.)}

Укрепив собственную финансово-денежную систему, Советский Союз в последующие годы сумел оказать необходимую помощь Тувинской Народной Республике. Так, после попытки министерства финансов ТНР провести денежную реформу в 1923 г., когда были выпущены правительственные боны, предназначенные для выплаты зарплаты служащим, денежное обращение в республике еще более осложнилось (Тульчинский, 1961: 274). По мнению А.Я. Ананьина, это были дореволюционные денежные знаки царской России с надпечаткой, выполненной на старомонгольском и русском языках. Надпечатка была сделана на оборотной стороне кредитных билетов достоинством в 1 рубль 1898 г., 3 рубля 1905 г., 5 рублей 1909 г., и 10 рублей 1909 г. При этом автор отмечает, что не располагает достоверными архивными материалами по данной эмиссии (Ананьин, Рогов, 2014: 134). Эти уникальные деньги хранятся в фондах Национального музея им. Алдан-Маадыр Республики Тыва (Харунова, Харунов, Санчай, 2019: Электр. ресурс).

Однако, эти денежные знаки не получили признания у населения. Единственным правильным выходом в сложившейся ситуации правительство республики признало введение советской валюты с разрешения СССР. «В 1925 г. в обращение были выпущены советские деньги: серебряные монеты - рубли, чуть позже - бумажные казначейские и банковские билеты» (Копеел, 1981: 83). Правительство через си-

${ }^{1}$ Русская самоуправляющаяся трудовая колония существовала на территории Тувы с 1922 года по 1932 год. 
стему Тувинбанка скупало разнообразную валюту у населения и обменивало на советский рубль. Один лан обменивался на 1 руб. 43 коп.

Для закрепления советского рубля в 1926-1929 гг. был издан ряд постановлений, запрещающих натуральный обмен и пользование иной валютой, кроме советской. Например, постановление ЦК ТНРП от 14 марта 1929 г., в котором также устанавливались твердые розничные цены на основные виды товаров широкого потребления (Копеел, 1981: 83).

Всего за период с 1925 по 1932 г. в ТНР было ввезено 3130005 руб. (из них частными лицами через таможенный пост - 94125 руб.), вывезено в СССР - 1268810 руб. (частными лицами - 80130 руб.), оставалось в ТНР - 1861915 руб. Деньги ввозились через Семиозерский таможенный пост, через таможенный пост на Большом пороге. При этом остались не учтенными суммы денег, завезенные из СССР тувинскими и русскими охотниками, минусинскими извозчиками в обход таможенных постов (Копеел, 1981: 84-85).

На основании Постановления Совета Министров ТНР от 12 мая 1932 г. за №57 министерство финансов и правление Тувинбанка заключили соглашение о выполнении учреждениями Тувинбанка кассовых функций по исполнению госбюджета ТНР, местных бюджетов, как в доходной так и в расходной их частях на всей территории ТНР (ГА РТ, Ф. 113, оп. 1, д. 54, л. 87). Министерство финансов выплачивало Тувинбанку 11000 руб. для содержания аппарата, изготовления книг, бланков, квитанций общеустановленного образца. Минфин осуществлял надзор за правильностью работы учреждений Тувинбанка в области кассового исполнения государственного и местного бюджетов и производства операций по специальным средствам и депозитам.

В мае 1933 г. ситуация с денежным обращением акционерами Тувинбанка была признана больным вопросом. В связи с разной стоимостью товаров в Туве и СССР в республику стало проникать контрабандным путем большое количество денежных знаков. Особенно большой наплыв денежных знаков из СССР произошел в 1932-1933 гг., что вызвало в ТНР повышение рыночных цен на товары народного потребления и продукты питания.

Так, из воспоминаний местных старожилов, цены на базаре города Кызыла значительно выросли по сравнению с 1926 г. Из таблицы 3 мы видим, что стоимость на некоторые виды товаров выросла в 2-7 раз (Ананьин, Рогов, 2014: 135).

Таблица 3. Стоимость товаров в ТНР в 1926 и 1932 г2., в руб. Table 3. Cost of goods in PRT, 1926 and 1932, in rubles.

\begin{tabular}{|c|c|c|}
\hline Товар & 1926 г. & 1932 г. \\
\hline Живой баран & 8 руб. & 19 руб. \\
\hline Картофель (1 мешок) & 2 руб. & 6 руб. \\
\hline Воз сена & 4 руб. & 25 руб. \\
\hline
\end{tabular}

Некоторые исследователи считают, что резкое увеличение находящейся в обороте денежной массы с 1925 по 1933 г. в ТНР и отсутствие возможности регулирования денежным обращением (денежные знаки были валютой СССР) стали одной из предпосылок для введения в обращение собственной национальной валюты в республике (Ананьин, Рогов, 2014: 135).

Постановление Правительства ТНР о проведении денежной реформы и введении национальной валюты было принято 16 сентября 1933 г. Постановлением было установлено наименование тувинской национальной валюты - акша, покупюрный состав вводимых банковских билетов и срок обмена находившихся в обращении советских денежных знаков. 19 сентября 1933 г. Совет Министров ТНР обратился к СССР с просьбой об оказании помощи в изготовлении национальных денежных знаков (Копеел, 1981: 86). Планировалось выпустить национальную валюту в обращение с 1 марта 1934 г., однако для этого требовалась серьезная подготовка. В связи со сложностью проведения данной реформы Постановление не было выполнено в срок.

В декабре 1933 г. Советом Министров и Президиумом Малого Хурала было принято постановление о выпуске в обращение новых штемпелеванных денежных знаков со штампом «Кара cangьs T.A.R. istinge cүgyrer ergelig»- переводится на русский язык как «Имеет право хождения только на территории ТНР» 
(Харунова, Харунов, Санчай, 2019: Электр. ресурс). Для этого использовали советские рубли номиналами в 1 рубль 1928 г., 3 и 5 рублей 1925 г. и билеты Государственного банка в 1 червонец 1926 г. и 2 червонца 1928 г.

Данная мера должна была стабилизировать количество денег в обращении. Тувинбанку поручалось произвести обмен всех находящихся в обращении денег на банковские и казначейские билеты СССР со штампом «Кара cangьs T.A.R. istinge cygyrer ergelig». Эти денежные знаки обращались в ТНР до 1935 г.

Обмен был произведен в срок с 10 декабря 1933 г. по 15 января 1934 г. через кассы Тувинского торгово-промышленного банка и сберегательные кассы. Замена советского рубля на проштампованные денежные знаки привела к тому, что на 1 января 1934 г. в обращении находились 1660000 руб. (Копеел, 1981: 85). К 15 февраля 1934 г. в Тувинбанк в результате обмена поступила сумма дензнаков без штампа на 1763277 руб. (Ананьин, Рогов, 2014: 135). Так постепенно создавались предпосылки для дальнейшей денежной реформы.

В. А. Копеел писал: «Регулирование денежного обращения осуществлялось Тувинбанком, исходя из количества денег в обращении и потребностей в наличных деньгах. Однако в силу ряда причин не представлялось возможным в полной мере учитывать движение денежных потоков и точно определять массу денег, находящуюся в обращении. ... Не было и кассового плана банка, в котором устанавливаются источники и объем поступлений наличных денег в кассы, определяются назначение и размеры выдачи денег из банка. Лишь в бюджете республики в какой-то мере учитывалось движение денежных средств в безналичном и наличном денежном оборотах. Отрицательно сказывалось на состоянии денежного обращения и отсутствие собственной валюты страны» (Копеел, 1981: 84).

Таким образом, период с 1921 по 1935 г. можно определить первым переходным этапом денежной реформы в ТНР, когда были сформированы предпосылки введения тувинской национальной валюты акша. В результате развития товарно-денежных отношений натуральный обмен уступил место системе купли-продажи. Введение советского рубля с 1925 г. упорядочило денежное обращение в одной валюте, была создана основа финансово-кредитной системы в виде государственных органов, банка и торговых организаций, образован государственный бюджет и налоговое обложение.

\section{Денежная реформа 1935 2.}

Все правительственные мероприятия, связанные с упорядочением денежного обращения и организацией органов финансового управления в республике до 1935 г. подготовили почву для проведения денежной реформы и введения собственной национальной валюты - акша.

По заказу Правительства ТНР Госзнак СССР на Монетном Дворе г. Ленинграда в 1934 г. отчеканил монеты тувинской национальной валюты с номиналами 1, 2, 3, 5, 10, 15 и 20 копеек.

Бумажные денежные знаки были напечатаны в 1935 г. с номиналами 1, 3, 5, 10 и 25 акша (фото 1 u 2).

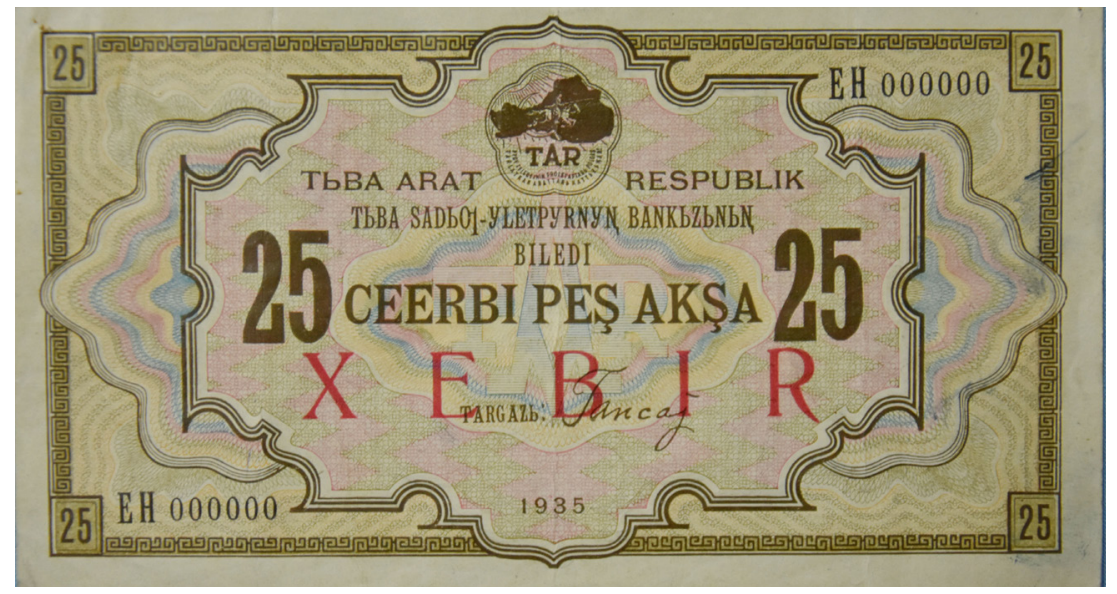

Фото 1. 25 акша 1935 г., лицевая сторона, образец. Национальный музей Республики

Тыва, Ф. 10, ДПИ, шкаф № 15, полка 13, коробка 1. Фото А. Д. Куулар, 2018 г. Photo 1.25 aksha (1935 issue), obverse. National Museum of the Republic of Tuva, F.10, DPI, Cab.15, Shelf 13, Box 1. Photo by A. D. Kuular, 2018. 
Деньги ТНР были изготовлены на Госзнаке СССР на общую сумму 2000000 акша (Ананьин, Рогов 2014: 137). Количество купюр по номиналам и их стоимость приведены в таблице 4.

Таблица 4. Акща 1935 года выпуска (номинал и количество купюр).

Table 4. Aksha (1935 issue), face value and number of banknotes.

\begin{tabular}{|c|c|c|}
\hline $\begin{array}{c}\text { Номинал, } \\
\text { акша }\end{array}$ & $\begin{array}{c}\text { Сумма, } \\
\text { акша }\end{array}$ & Кол-во купюр, шт. \\
\hline 1 & 400000 & 400000 \\
\hline 3 & 600000 & 200000 \\
\hline 5 & 500000 & 100000 \\
\hline 10 & 300000 & 30000 \\
\hline 25 & 200000 & 8000 \\
\hline
\end{tabular}

Первый выпуск бумажных денег, официально именуемый «Билетами Министерства финансов ТНР», по факту явился атрибутом государственного суверенитета ТНР. С их выпуском окончательно был вытеснен натуральный обмен, укрепилась база расчетной системы, налогообложения, госбюджета. Трудно переоценить роль первого выпуска бумажных денег ТНР, ставшего серьезным средством и фактором экономического развития молодой республики.

Одновременно был произведен обмен металлической разменной монеты СССР на вновь изготовленные тувинские монеты 1934 г. И монеты, и бумажные деньги были пущены в оборот одновременно в середине 1935 г. Котировка тувинского акша была установлена в соотношении 1:1 по отношению к советскому рублю.

Монеты всех достоинств были отчеканены в количестве, достаточном для обращения - каких-либо дополнительных выпусков за девять лет их обращения не было. В отличие от монет бумажные деньги ТНР имели два выпуска - 1935 и 1940 гг. Это было связано с тем, что все номиналы тувинских банкнот 1935 г. были выпущены, как было принято в царской и советской России, с подписью управляющего Тувинским торгово-промышленным банком ТНР Оюна Танчая, судьба которого сложилась трагично.

Оюн Танчай Чырандай (1893-1938 гг.) занимал высокие государственные должности министра финансов ТНР (1922-1923 гг.), посла ТНР в СССР (1926-1927 гг.), министра иностранных дел (1927-1932 гг.), Председателя государственно-плановой комиссии ТНР (1932-1933 г.), Председателя Тувинского торгово-промышленного банка ТНР (1934-1936 гг.) (ГА РТ, Ф. 1, Оп. 2, Д. 232, л. 1). По обвинению в шпионаже в пользу Японии был снят с постов и исключен из рядов Тувинской народной революционной партии в декабре 1937 г., а затем арестован и расстрелян в октябре 1938 г. Реабилитирован посмертно в сентябре 1964 г.

Денежные купюры 1935 г. выпуска с подписью репрессированного руководителя Тувинбанка Оюна Танчая подверглись репрессиям так же, как и один из их создателей.

В государственном архиве Республики Тыва хранятся документы с протоколами допросов Оюна Танчая. В одном из них секретарь скрупулезно зафиксировал следующие его слова: «Тувинское государство - не капиталистическое, не социалистическое и не революционное, оно такое, какое есть» (ГА РТ, Оп. 2, Ф. 2, Д. 232, л. 36). Это короткая фраза свидетельствует об аналитическом складе ума этого человека, объективно оценивавшего сложный хозяйственно-экономический уклад ТНР. К этому же выводу о многоукладности экономики Тувы в результате своей исследовательской работы пришла В. В. Осипова: «Накануне 30-х годов в экономике ТНР было пять социально-экономических укладов: социалистический, мелко-товарный, патриархальный, феодальный, капиталистический. В соотношении со всеми перечисленными укладами в экономике Тувы находились соответствующие им общественные классы» (Осипова, 1961: 122).

\section{Денежная реформа 1940 года}

В августе 1939 г. правительственная комиссия рассмотрела проекты денежных знаков достоинством в 1, 3, 5 и 25 акша. Проект номиналом в 10 акша отсутствовал. Образцы новых денежных знаков были 
утверждены в 1940 г., и заказ был размещен на печать в СССР. Всего на разработку, изготовление и доставку банкнот нового образца было израсходовано 136 346, 43 акша. В феврале 1941 г. были получены 75 посылок тувинской валюты второго выпуска образца 1940 г., принятые от Госбанка СССР в г. Абакане. Общая сумма купюр составляла 1999999 акша (Ананьин, Рогов, 2014: 137). Количество купюр по номиналам и их стоимость приведены в таблице 5.

Таблица 5. Акша 1940 года выпуска (номинал и количество купюр). Table 4. Aksha (1940 issue), face value and number of banknotes.

\begin{tabular}{|c|c|c|}
\hline Номинал, акша & $\begin{array}{c}\text { Сумма, } \\
\text { акша }\end{array}$ & Кол-во купюр, шт. \\
\hline 1 & 300000 & 300000 \\
\hline 3 & 399999 & 133333 \\
\hline 5 & 500000 & 100000 \\
\hline 10 & 500000 & 50000 \\
\hline 25 & 300000 & 12000 \\
\hline
\end{tabular}

С 1 марта 1941 г. были выпущены в обращение денежные знаки тех же достоинств, что и в первом выпуске 1935 г.: в 1, 3, 5, 10 и 25 акша. «...Поступила первая партия тувинских акша второго выпуска, но уже без чьей-либо подписи - на всякий случай. Таково было время, таковыми стали и деньги - с невидимым отражением страха и неуверенности», - подчеркивает К. А. Бичелдей (Бичелдей, 2009: 23).

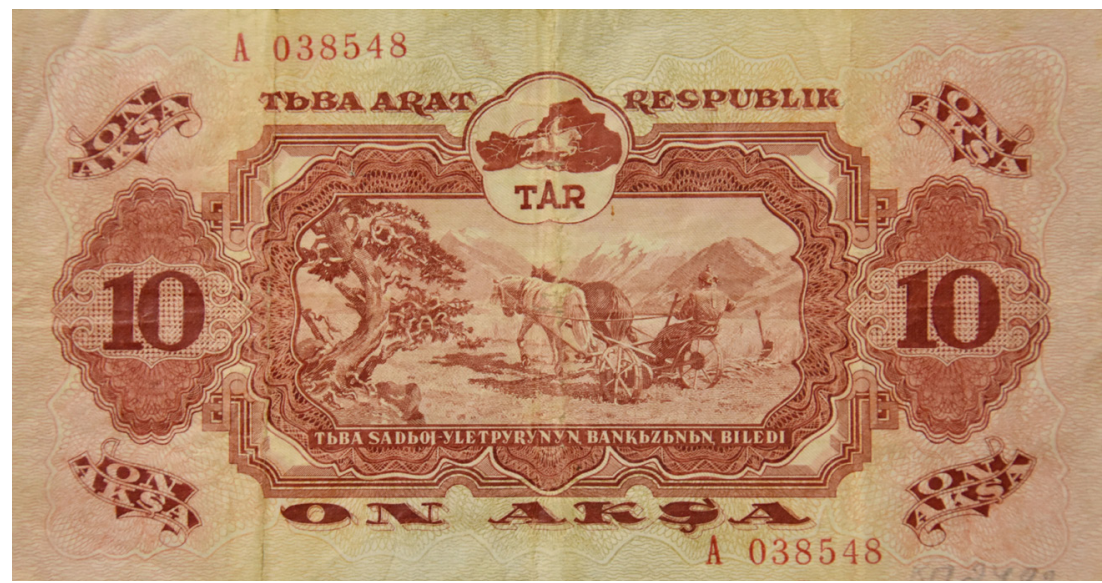

Фото 2. 10 акша 1940 г., лицевая сторона. Национальный музей Республики Тыва, Ф. 10, ДПИ, шкаф № 15, полка 13, коробка 1. Фото А. Д. Куулар, 2018 г.

Photo 2. 10 aksha (1940 issue), obverse. National Museum Republic of Tuva, F.10, DPI, Cab. 15, Shelf 13, Box 1. Photo by A. D. Kuular, 2018.

Обмен денег старого образца на новые был произведен до 1 сентября 1941 г. «Изъятые денежные знаки образца 1935 года 2 октября 1941 г. были полностью пересчитаны, а 5 октября того же года уничтожены в присутствии членов правительственной комиссии, состоящей из пяти человек: министр финансов ТНР Самбу, члены комиссии: зам. министра внутренних дел ТНР - Артас, управляющий Тувинбанком - Мирошниченко, председатель Ревкомиссии банка - Самба-Люндуп» (Ананьин, Рогов, 2014: 137). Из денежных знаков на сумму 2000000 акша 1935 г. выпуска было подготовлено к уничтожению на сумму 1981248 акша. У населения на руках остались следующие банковские билеты: 1 акша - 4822 шт., 3 акша - 1560 шт., 5 акша - 1217 шт., 10 акша - 224 шт., и 25 акша - 37 шт. (Ананьин, Рогов, 2014: 140).

Второй выпуск акша находился в обращении около четырех с половиной лет. 


\section{Документирование денежного обращения}

По объективным причинам денежная реформа и последовавшие изменения в формировании бюджета, налоговой политики и других финансово-кредитных институтов реализовывались с большими затруднениями. Совет министров ТНР 11 августа 1939 г. принял Постановление об отчетности государственных и хозяйственных учреждений и предприятий (ГА РТ, Ф. 113, оп. 1, д.122, л.156). В связи с тем, что государственные учреждения и предприятия, находящиеся на государственном и местном бюджетах, несвоевременно вели квартальный учет и отчет своих расходов и доходов, безответственно относились к составлению смет на хозяйственные и строительные расходы, в середине бюджетного года для них приходилось выделять дополнительную сумму средств. Например, полугодовой отчет за 1939 г. не был составлен следующими организациями: Совтувтранс, Гостехснаб, Гостипография, Минпромторг, Минкульт, Гос.электростанция. Некоторые организации задерживали внесение государству таможенного налога, такие как Совтувтранс и Туваптека (ГА РТ. Ф. 113, оп. 1, д.122. л.157).

Всем бюджетным организациям вменялось укрепление финансовой дисциплины, увеличение доходной части финансового хозяйства, своевременное оформление учетности и отчетности, правильное использование средств госбюджета. В течение месяца требовалось погасить межведомственную задолженность. Министерству финансов поручалось усилить контроль и учет финансового состояния учреждений, вести решительную борьбу с незаконным расходованием бюджетных средств; совместно с Тувинбанком и Тувценкоопом периодически проводить совещания финансовых и счетных работников, на которых бы обсуждались конкретные вопросы, способствующие улучшению качества их работы, организовывать обмен опытом.

Арбитражной комиссии в 10-дневный срок поручалось решить все спорные вопросы, связанные с ведомственной задолженностью. А те вопросы, которые не могут быть решены арбитражной комиссией, следовало передать в судебные органы, которые должны были рассмотреть дела в течение 15 дней. Суду разрешалось принимать меры вплоть до закрытия текущего счета учреждения, а в отношении частных лиц - до конфискации имущества (ГА РТ. Ф. 113, оп. 1, д.122, л.159).

Тувинский торгово-промышленный банк отслеживал динамику денежного обращения в стране и движение кассовой наличности (см таблицу 6). В объяснительной записке «К сводному годовому отчету Тувинбанка за 1940 год» отмечалось следующее: «...В результате введения в 1936 г. национальной валюты акша, окончательно заложившей здоровую основу для денежного обращения в стране, благодаря оздоровлению товарооборота, мобилизации денежных средств населения и внедрению безналичных расчетов между организациями, покупательная способность валюты остается совершенно устойчивой и оборачиваемость ее все более увеличивается» (ГА РТ. Ф.113, Оп. 1, Д. 114, л. 43).

Таблица 6. Денежное обращение в Туве в 1930-1941 г2. Table 6. Money circulation in Tuva in 1930-1941.

\begin{tabular}{|l|l|l|}
\hline На 1 января 1930 г. & рублей & 1459,0 тыс. \\
\hline На 1 января 1931 г. & рублей & 1636,0 тыс. \\
\hline На 1 января 1932 г. & рублей & 2 008, 0 тыс. \\
\hline На 1 января 1933 г. & рублей & 1660,0 тыс. \\
\hline На 1 января 1934 г. & рублей & 970,0 тыс. \\
\hline На 1 января 1935 г. & рублей & 920 тыс. руб. \\
\hline На 1 января 1936 г. & рублей & 996,0 тыс. \\
\hline На 1 января 1937 г. & акша & 880,4 тыс. \\
\hline На 1 января 1938 г. & акша & 911,4 тыс. \\
\hline На 1 января 1939 г. & акша & 909,0 тыс. \\
\hline На 1 января 1940 г. & акша & 908,0 тыс. \\
\hline На 1 января 1941 г. & акша & \\
\hline
\end{tabular}


В сравнении с товарооборотом и количеством населения в стране, динамика денежного обращения за 1937-1941 гг. характеризовалась следующими показателями (см. таб. 7).

Таблища 7. Динамика денежного обращения в Туве за 1937-1941 22. Table 7. Dynamics of money circulation in Tuva in 1937-1941.

\begin{tabular}{|c|c|c|c|c|c|}
\hline Наименование & На 1/1 1937 г. & На 1/1 1938 г. & На 1/1 1939 г. & На 1/1 1940 г. & На 1/1 1941 г. \\
\hline \multicolumn{6}{|l|}{ I } \\
\hline $\begin{array}{c}\text { Сумма находящихся в } \\
\text { обращении денег } \\
\text { (в тыс. акша) }\end{array}$ & 996,0 & 880,0 & 911,4 & 909,0 & 908,0 \\
\hline $\begin{array}{l}\text { Кол-во населения } \\
\text { (в тыс. чел.) }\end{array}$ & 82,7 & 84,7 & 86,2 & 86,7 & 90,2 \\
\hline $\begin{array}{c}\text { Приходится на } 1 \text { чел. (в } \\
\text { акша) }\end{array}$ & 12,24 & 10,39 & 10,57 & 10,48 & 10,04 \\
\hline \multicolumn{6}{|l|}{ II } \\
\hline $\begin{array}{c}\text { Средняя годовая масса } \\
\text { денег, находившихся в } \\
\text { обращении } \\
\text { (в тыс. акша) }\end{array}$ & 819,0 & 963,0 & 936,6 & 914,75 & 928,5 \\
\hline $\begin{array}{c}\text { Весь товарооборот } \\
\text { (за } 1940 \text { г. } \\
\text { ориентировочно) }\end{array}$ & 13813,1 & 15681,4 & 15556,6 & 14968,0 & $14,372,0$ \\
\hline $\begin{array}{c}\text { Соотношение } \\
\text { денежной массы к } \\
\text { товарообороту }\end{array}$ & $5,93 \%$ & $6,14 \%$ & $6,02 \%$ & $6,11 \%$ & $6,45 \%$ \\
\hline
\end{tabular}

(ГА РТ. Ф. 113, Оп. 1, Д. 114, Л. 44).

Из таблицы 7 видно, что количество находящихся в обороте денег после выпуска национальной валюты оставалось почти стабильным, шло постепенное наращивание денежной массы к товарообороту.

Также для банка немаловажным был кадровый вопрос, который постоянно отслеживался. На 1 января 1941 г. в банке работали 55 сотрудников (ГА РТ. Ф. 113, оп. 1, д. 114, л. 52). Но за предыдущий год кадровый состав изменился на 50\%. Такая текучесть кадров вызвала необходимость срочной подготовки специалистов. На курсах при управлении банка было подготовлено 11 человек, которые были направлены в отделения банка на должности заведующих, бухгалтеров и кассиров. Управление, согласно решению Совета банка, забронировало в Кызыльском учебном комбинате 5 человек с последнего курса с оплатой их трехлетнего обучения. Кроме того, Управление дало согласие на обучение трех человек в СССР. Из этого следует, что банк не только осуществлял подготовку квалифицированных кадров, но и готовил их резерв (ГА РТ. Ф. 113, оп. 1, д. 114,л. 53).

Для упорядочивания денежного оборота Совет министров ТНР 2 мая 1942 г. утвердил «равила по денежному обращению в THР» («TAR-nъn istinde aksa ergildezinin curumu») на русском и тувинском языках (ГА РТ. Ф. 113, оп.1, д.122, л.65). Правила устанавливали порядок хранения денежных средств, расходов выручки, поступление и сдачу налогов, сборов, членских взносов и др., а также начисление и выдачу зарплаты, порядок работы с кассовыми планами. Контроль за исполнением «Правил» возлагался на министерство финансов ТНР и Тувинбанк.

С вхождением Тувы в состав СССР 11 октября 1944 г. тувинская национальная валюта акша была изъята из оборота и в первой половине 1945 г. заменена на советские рубли по курсу 1 акша на 3 руб. 50 коп. (Тульчинский, Каплунов, 1972: 36). Это обстоятельство свидетельствует о патерналистской политике Советского Союза, заинтересованного в улучшении общего социально-экономического положения Тувы и ее населения после вхождения в состав СССР. 


\section{Заключение}

Таким образом, создание национальной денежной системы в Туве стало сложным и многоэтапным процессом. Это было обусловлено слаборазвитыми товарно-денежными отношениями в крае к началу $\mathrm{XX}$ века. По мере политического сближения Тувы с Российской империей, а затем Советским Союзом, шло постепенное становление и укрепление денежных отношений. При поддержке СССР Тувинская Народная Республика провела в середине 1920 - начале 1930 гг. ряд реформ, позволивших в 1935 г. ввести акша - тувинскую национальную валюту. Акша 1935 и 1940 годов выпусков являлась денежной единицей ТНР в течение девяти лет.

Пережив на себе вместе с одним из ее создателей Оюном Танчаем репрессии, акша стала символом зарождения нового государства в Центре Азии на новых политических и экономических основах, олицетворяя собой переход традиционного кочевого общества к многоукладному, с зарождающимся промышленным производством и развитыми товарно-денежными отношениями. Сегодня акша является не только уникальным явлением в мире нумизматики, но и ее название навсегда закрепилось в современном тувинском языке, обозначая в целом деньги.

Можно согласиться с Л.И. Тульчинским, который выделял следующие этапы становления финансово-кредитной системы ТНР в увязке с поступательным развитием ее экономики. Первый этап с 1921 по 1931 гг., - в этот период становилась тувинская государственность, начало развиваться народное хозяйство и культура, зарождались тувинские финансы. Второй этап с 1931 по 1944 гг. - до вхождения Тувы в состав СССР - характеризовался укреплением тувинского государства, развитием всех отраслей народного хозяйства и культуры, становлением и укреплением нового уклада в экономике. На третьем этапе - с 1944 по 1953 г. - завершились социально-политические преобразования в экономике и культуре Тувы (Тульчинский, 1961: 270).

Формирование собственной денежной системы с введением национальной валюты упорядочило товарно-денежные отношения в ТНР и стало основой создания и укрепления молодого государства. Произошло поэтапное становление главных финансово-экономических институтов, таких как налоговая, кредитная политика и государственный бюджет, а также развитие основных отраслей экономики страны. Акша сыграла ключевую роль в создании системы управления финансами. В конечном итоге именно этот фактор способствовал достаточно быстрой адаптации экономики и финансов ТНР после принятия Тувы в состав СССР к советской системе финансовых и экономических отношений.

\section{СПИСОК ЛИТЕРАТУРЫ}

Ананьин, А. Я., Рогов, Г. И. (2014) Денежные знаки Тувы // Антиквариат, предметы искусства и коллекционирования. № 9 (119). С. 134-143.

Аранчын, Ю. Л. (1982) Исторический путь тувинского народа к социализму. Новосибирск : Наука. 337 c.

Бичелдей, К. А. (2009) Денежная реформа ТНР 1925-1940 гг. - банкноты и монеты Тувы как предмет нумизматики (по фондовым материалам Национального музея Республики Тыва) // Наследие народов Центральной Азии и сопредельных территорий: изучение, сохранение и использование. Материалы научно-практической конференции, г. Кызыл, 9-10 сентября 2009 г.: в 2-х ч. / сост. У. Б. Нурзат. Кызыл : КЦО «Аныяк». Ч. 1.199 с. С. 18-26.

Денежное обращение и кредит СССР (1986) / под ред. В. С. Геращенко. М. : Изд-во «Финансы». 244 с.

Иезуитов, В. М. (1956) От Тувы феодальной к Туве социалистической. Кызыл : Тувинское книжное издательство. 208 с.

История Банка России, 1860-2010 (2010): в 2 т. / Банк России; ред. совет: Г. И. Лунтовский (пред.) [и др.]; отв. ред.: Ю. А. Петров, С. В. Татаринов. М. : Изд-во РОССПЭН. Т. 2.: Государственный банк СССР. Центральный банк Российской Федерации (Банк России). 679 с.

История Тувы (2007): в 3 т. / под общ. ред. В. А. Ламина. Новосибирск : Наука. Т. 2.430 с.

Конституции Тувы (1999). Кызыл : Тувинское книжное издательство. 216 с.

Копеел, В. А. (1981) Деньги и денежное обращение в период ТНР // По пути Великого Октября. К 60-летию Народной революции в Туве / отв. ред. Ю. Л. Аранчын. Кызыл : Тувинское книжное издательство. 156 c. C. $81-89$. 
Осипова, В. В. (1961) Сельскохозяйственная и демографическая перепись 1931 года, как важнейший источник характеристики экономического строя сельского хозяйства Тувы (1921-1930 гг.) // Ученые записки. Вып. ІХ. Кызыл : Типография управления культуры. С. 99-124.

Татаринцев, Б. И. (2015) Этимологический словарь тувинского языка: в 4 т. Абакан : ООО «Кооператив «Журналист». Т. 1.398 с.

Тульчинский, Л. И. (1961) К вопросу о зарождении и развитии финасово-кредитной системы в Туве (1921-1944 гг.) // Ученые записки. Выпуск IX. Кызыл : Типография управления культуры. С. $269-274$.

Тульчинский, Л. И., Каплунов, А. И. (1972) Очерки бюджета Тувы / отв. ред. В. П. Солдатов. Кызыл: Тувинское книжное издательство. 136 с.

Харунова М. М.-Б., Харунов Р. Ш., Санчай Ч. О. (2019) Деньги Тувинской Народной Республики в коллекциях Национального музея Тувы [Электронный ресурс] // Новые исследования Тувы. № 2. URL: http// nit.tuva.asia/article/view/849 (дата обращения: 03.05.2019.). DOI:10.25178/nit/2019/2.9

Дата поступления: 15.05.2019 2.

\section{REFERENCES}

Anan'in, A. Ya. and Rogov, G. I. (2014). Denezhnye znaki Tuvy [Currency notes of Tuva]. Antikvariat, predmety iskusstva i kollektsionirovaniya, no. 9 (119), pp. 134-143. (In Russ.).

Aranchyn, Yu. L. (1982) Istoricheskii put' tuvinskogo naroda $k$ sotsializmu [The historical path of the Tuvan people to socialism]. Novosibirsk, Nauka. 337 p. (In Russ.).

Bicheldei, K. A. (2009) Denezhnaia reforma TNR 1925-1940 gg. - banknoty i monety Tuvy kak predmet numizmatiki (po fondovym materialam Natsional'nogo muzeia Respubliki Tyva) [The monetary reform of the People's Republic of Tuva, 1925-1944: Banknotes and coins of Tuva as a subject of numismatics (from the collections of The National Museum of the Republic of Tuva)]. In: Nasledie narodov Tsentral'noi Azii i sopredel'nykh territorii: izuchenie, sokhranenie I ispol'zovanie [The heritage of the peoples of Central Asia and adjacent territories: research, preservation and use]. Proceedings of a conference, September 9-10, 2009, Kyzyl: in 2 vols. / ed. by U. B. Nurzat. Kyzyl, KTSO «Anyiak». Vol. 1. 199 p. pp. 18-26. (In Russ).

Denezhnoe obrashchenie I kredit SSSR [Money circulation and credit inf the USSR] (1986) / ed. by V. S. Gerashchenko. Moscow, Finansy Publ. 244 p. (In Russ.).

Iezuitov, V. M. (1956) Ot Tuvy feodal'noi k Tuve sotsialisticheskoi [From feudal Tuva to Socialist Tuva]. Kyzyl, Tuvan book publ. 208 p. (In Russ.).

Istoriya banka Rossii. 1860-2010 [A history of the Bank of Russia 1860-2010] (2010) : in 2 vol. Moscow, ROSSPEN. Vol. 2.679 p. (In Russ).

Istoriia Tuvy [The History of Tuva] (2007): in 3 vols. / ed. by V. A. Lamin. Novosibirsk, Nauka Publ. Vol. 2. 430 p. (In Russ).

Konstitutsii Tuvy [Constitutions of Tuva] (1999). Kyzyl, Tuvan book publishing house. 216 p. (In Russ).

Kopeel, V. A. (1981) Den'gi i denezhnoe obrashchenie v period TNR [Money and money circulation in the PRT]. In: Po puti Velikogo Oktyabrya. K 60-letiyu Narodnoi revolyutsii v Tuve [On the path of the Great October: Dedicated to the 60th anniversary of People's Revolution in Tuva]. Kyzyl, Tuvan book publ. 156 p. Pp. 81-89. (In Russ.).

Osipova V.V. (1961) Sel'skokhozyaistvennaia i demograficheskaia perepis' 1931 goda, kak vazhneishii istochnik kharakteristiki ekonomicheskogo stroya sel'skogo khoziaistva Tuvy (1921-1930 gg.) [The agricultural and demographic census of 1931 as a crucial source for the study of the economic structure of agriculture in Tuva, 1921-1930]. In: Uchenye zapiski. Vol. IX. Kyzyl, Tipografiya upravleniya kul'tury. Pp. 99-124. (In Russ.).

Tatarintsev, B. I. (2015). Etimologicheskii slovar' tuvinskogo yazyka [An etymological dictionary of the Tuvan language]: in 4 vols. Abakan, OOO Kooperativ «Zhurnalist». Vol. 1. 398 p. (In Russ.).

Tul'chinskii, L. I. (1961). K voprosu o zarozhdenii i razvitii finansovo-kreditnoi sistemy v Tuve (1921-1944 gg.). [On the birth and rise of the system of Tuvan finance and credit, 1921-1944]. In: Uchenye zapiski. Vol. IX. Kyzyl, Tipografiya upravleniya kul'tury. Pp. 269-274. (In Russ.).

Tul'chinskii, L.I. and Kaplunov, A.I. (1972) Ocherki biudzheta Tuvy [Essays on the budget of Tuva], ed. V. P. Soldatov. Kyzyl, Tuvan book publ. 136 p. (In Russ.). 
НОВЫЕ ИССЛЕДОВАНИЯ ТУВЫ

www.nit.tuva.asia

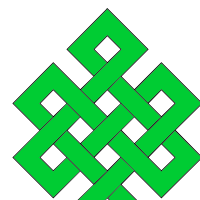

THE NEW RESEARCH OF TUVA

Novye issledovaniia Tuvy

Kharunova, M. M.-B., Kharunov, R. Sh. and Sanchai, Ch. O. (2019) Money of the People’s Republic of Tuva in the collections of the Aldan-Maadyr National Museum of Tuva. The New Research of Tuva, no. 2 [online] Available at: https://nit.tuva.asia/nit/article/view/849 (access date: 03.05.2019.). DOI: 10.25178/nit.2019.2.9

Submission date: 15.05.2019. 